\title{
The Causality of Qatar, Kuwait, and the United Arab Emirates Sharia Stock Indices on Indonesian Sharia Stock Index
}

\author{
Anisah Firli ${ }^{1}$, Satria Jayasena ${ }^{2}$ \\ ${ }^{1,2}$ School of Economic and Business, Universitas Telkom, Bandung, Indonesia \\ anisahfirli@gmail.com, anisahfirli@telkomuniversity.ac.id
}

\begin{abstract}
The capital market plays an important role in encouraging the investment, economy, and prosperity of a country. The sharia capital market was formed to be a new alternative in investing. The movement of the capital market can be influenced by various factors, one of which is the influence of other countries, also known as contagion, which in turn causes causality between the stock indices of each country. This study was conducted to determine whether there was a causal relationship between the sharia stock indices of Qatar and Indonesia, between the sharia stock indices of Kuwait and Indonesia, and between sharia stock indices of the United Arab Emirates and Indonesia. Stock index data of QERI, FTFLKS, FTDKUS, and ISSI for 5 years were tested using the Stationarity Test and the Granger Causality Test to determine the quality between indices. This study provides different findings from other studies, showing no causality in the sharia stock indices of Qatar, Kuwait, and the United Arab Emirates on Indonesia. The findings of this study can be used as input for investors in determining their investment portfolio if they wish to invest in the sharia capital market.
\end{abstract}

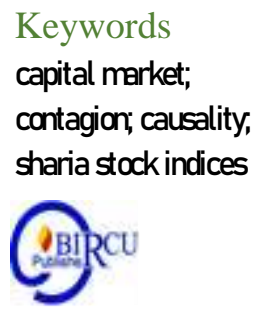

Keywords

capital market; contagion; causality, sharia stock indices

\section{Introduction}

In recent years, the sharia capital market has experienced rapid development in various countries. For example, the capital market in Indonesia has experienced very significant developments in the last four years, having its number of investors increased by 536\%. In August 2020, sharia stock investors reached 78,199 investors or 5.9\% of total stock investors in Indonesia. According to Rahmati et al. (2018), the development of the Islamic economy in Indonesia is very significant with many investors. Adzimatinur and Manalu (2021), said that Indonesia is included in the 7 countries with the largest total islamic financial assets in the world. With various achievements achieved by the sharia capital market, Indonesia was named The Best Islamic Capital Market at the 2020 Global Islamic Finance Awards (GIFA) (www.idx.co.id, 2020).

Sharia stocks, according to Bayram \& Othman (2019), are stocks meeting the criteria of Islamic law by avoiding the business of liquor, alcohol, gambling, pork, entertainment that are not in accordance with Islamic law. Capital market movements can be influenced by various economic, social, and political factors (Rakhal, 2015) and also demand and supply (Yusuf et al, 2018). In addition, Ahmadi (2016) explains that supply and demand can be influenced by the influence of other countries as a result of the globalization era. The contagion has been researched by several researchers to see the effect of a country's conditions on other countries due to the integration between these countries, which then produces an effect on stock movements. 
According to Uliviano (2013), the contagion effect can occur because of the economic dependence of a country. Vermonte (2017) mentions the cooperation between ASEAN and the Gulf Cooperation Council in petroleum commodity trade. Countries with the most trade relations with ASEAN countries are Qatar, Kuwait, and the United Arab Emirates. The Ministry of Foreign Affairs of the Republic of Indonesia (2018) states that Indonesia has had bilateral relations with Qatar since 1976 through cooperation in the fields of transportation, air, tourism, and agriculture. In addition, Indonesia has established bilateral relations with Kuwait since 1968 and diplomatic relations with the United Arab Emirates since 1976. Indonesia, Qatar, Kuwait, and the United Arab Emirates, as countries whose most of the residents are Muslim, are also members of the World Trade Organization (WTO), Organization of Islamic Cooperation (OIC), and the Non-Aligned Movement.

The word accompaniment consists of 2 syllables "damping" which means familiar (brothers). Close, a meeting that ends with "an" so "side by side" implies a full life of helping one another. Furthermore, given the prefix "pen" so that "companion" means accompanying also accompanying, there is always a state of grief or joy.4 Mentoring is cooperation between the counterparty and the client which is based on mutual respect and trust. Assistance is a teaching medium that is seen as very effective and effective in helping someone to facilitate or provide facilities for determining and solving problems and encouraging a sense of initiative in making decisions so that independence can be realized, in other words helping someone realize their dreams. (Asmuni, 2021)

Previous studies found that there is a causal relationship between the IDX Composite (IHSG) and Hang Seng (Ahmadi, 2016); Thailand SETI (Adisetiawan \& Ahmadi, 2018), Australia ASX, FTSE, STI, PSEi (Adityara 2012). Based on aforementioned background and previous studies, this study aims at proving whether the cooperation carried out will have a causal impact on the stock index of these countries (Indonesia, Qatar, Kuwait, and the United Arab Emirates) that focuses on the sharia stock indices that have not been studied before. Hence, this study is expected to provide benefits to capital market players in the consideration of portfolios in inter-country investment.

\section{Review of Literature}

A sharia capital market is a place that accommodates the process of buying/selling shares based on sharia principles established by authorized institutions for companies that meet sharia criteria and have no things that are contrary to sharia principles (Sutedi, 2013); (Haikal, 2011); (Yusuf et al., 2018). According to Tandelilin (2010), Sharia Stock Index is a summary number of the movement of sharia stock prices as a result of all sharia stocks listed on the stock exchange of a country.

One thing that distinguishes Islamic economics and conventional economics is the view of money function. Money, in conventional economics, not only serves as a means of exchange of goods but also as a means of temporary wealth storage. Contrary to that, Islam views money as a medium of exchange, not a store of wealth. As a means of exchange in the economy, the use of money must be in accordance with the goals of Islamic economics itself (maqashid shariah). Therefore, the type or form of money should be tailored to the purpose or the function itself. (Zahara, 2020) 


\subsection{Contagion}

In general, contagion can be interpreted as a shock of relations that can occur between national borders in both normal and critical situations. In a narrower sense, it is an event occurring in several countries due to a situation that occurred (Lee, 2012). Meanwhile, the Contagion Effect is a contagious crisis condition due to integration between countries such as trade relations, similar conditions, and macroeconomic policies (Trihadmini 2012; Harjito 2010).

\subsection{Causality Theory of Stock Index between Countries}

According to Chabachib \& Witjaksono (2011), the price index relationship between countries is caused by developments in world technology that allow investors to invest by considering this integration as an estimate for other capital market movements. Budi \& Sri (2015) state that close cooperation between countries can be one of the factors of the same movement. If an event occurs in a country, then other countries that have a close relationship can be affected by the risk. Dornbusch et al. (2010) state that the causality factor of stock prices can occur if one country experiences an economic crisis, which also affects other countries that have bilateral relations.

Research by Ahmadi (2016) investigated the causality of the stock index in 11 countries on the Indonesian stock index, showing that only one country had stock price causality on Indonesia, which was Hong Kong. Natsir et al. (2019) conducted research with another stock index, which was the Dow Jones Index, and the results of the study proved that there was long-term causality between the IHSG and the Dow Jones Index. This is contrary to the research of Gom (2013), stating that there was no causal relationship between the IHSG and the Dow Jones Index.

Adityara's research (2012) found a causal relationship between the Indonesian stock market and Australia, England, Singapore, and the Philippines. While the five ASEAN countries, namely Indonesia, Singapore, Malaysia, Thailand, and the Philippines have close cooperation in various state relations, the research results only proved that the causality of the stock index only occurs between the Indonesia and Thailand indices (twodirectional). Indices of other Asian countries such as Japan are proven to have causality with the Indonesian index in the research conducted by Ghiffari et al. (2017).

Another research by Yusuf et al. (2018), which was carried out by comparing the conventional stock index with the sharia stock index in Indonesia, showed the result that there was no causal relationship between these indices. The causality between conventional indices had also been studied by Treesa \& Anjali (2018) on the TOPIX and NIKKEI indices, which concluded that there was a causal relationship between the two indices. In a similar vein, Kumar (2019) showed the existence of a causal relationship between conventional indices in America, namely the NASDAQ and Dow Jones. Ata \& Bugan (2015) stated that there was a bilateral causal relationship between the conventional index and the sharia index. These findings were in contrast with the research of Jebran et al. (2017) that showed no causality relationship between conventional and sharia indices in Pakistan. This is in line with the research of Indrabudiman \& Winarningsih (2018), which also examined the Dow Jones Index and the International Islamic Index and found no causality relationship.

In the context of sharia stocks, Beik \& Fatmawati (2014) examined the causality of international sharia stock prices towards Jakarta sharia stock prices and concluded that the Japanese Dow Jones Islamic Market and the Dow Jones Islamic Index Market had causality with the Jakarta Islamic Index. 


\section{Research Methods}

Based on the literature review and previous research, it can be concluded that bilateral/cooperation/diplomatic and other relationships can lead to causality in the stock price indices between countries. The existence of the same characteristics, namely countries whose most of the residents are Muslim and the existence of bilateral/cooperation/diplomatic relations that occur between the Islamic countries such as Qatar, Kuwait, the United Arab Emirates, and Indonesia were thought to lead to causality in the sharia stock indices between these countries.

Hypothesis 1: There is a causal relationship in the sharia stock indices between Qatar and Indonesia

Hypothesis 2: There is a causal relationship in the sharia stock indices between Kuwait and Indonesia

Hypothesis 3: There is a causal relationship in the sharia stock indices between the United Arab Emirates and Indonesia

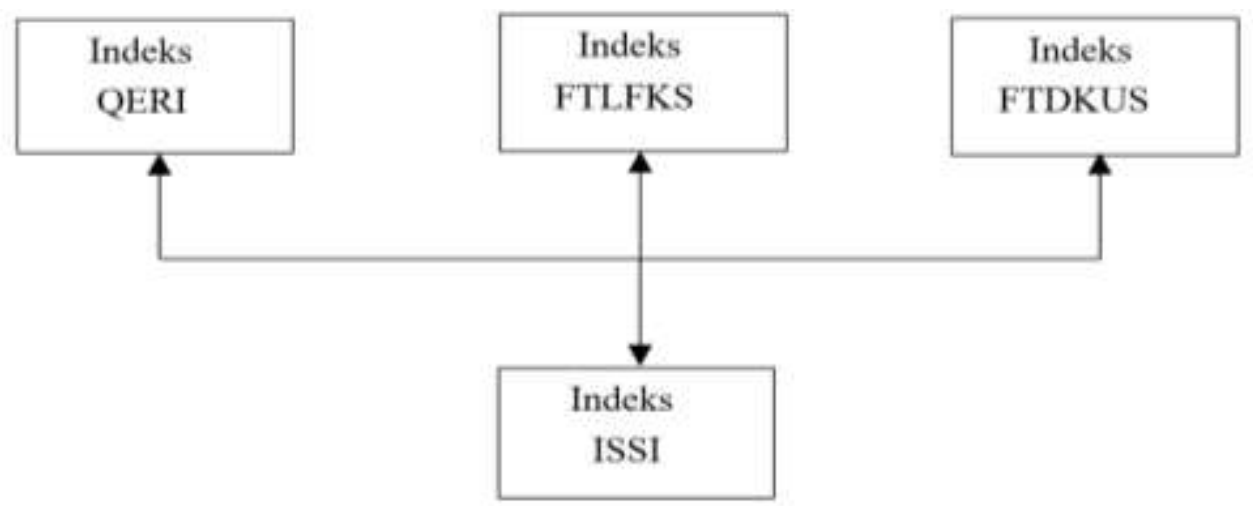

Figure 1. Research Framework

This study was conducted on the Sharia Stock Indices in Qatar (QERI), Kuwait (FTLFKS), United Arab Emirates (FDKUS), and Indonesia (ISSI) for 5 years (2013-2018) using the Granger causality test to find out which variables affect and are affected by other variables. The index calculation that was used refers to Widoatmodjo (2012) by comparing the total share prices at the prevailing time $(\mathrm{X})$ compared to the total share price at the base time $(\mathrm{Y})$ multiplied by $100 \%$. Index $=\frac{X}{Y} \times 100 \%$.

In the sharia stock index data, a stationary test was performed. A stationary test was performed to test whether the data was stationary or not. A stationary condition is a condition in which the mean, variance, and co-variance of the time series data are not influenced by time (Juanda \& Junaidi, 2012). Ahmadi (2016) used an equation model of:

Description:

$$
\Delta \mathrm{Yt}=\alpha 0 \mathrm{Y}+\alpha 1 \mathrm{~T}+\gamma 1 \mathrm{Yt}-1+\beta 1 \sum \Delta \mathrm{Yt}-1+\varepsilon \mathrm{t}
$$

$$
\begin{array}{ll}
\mathrm{Yt} & : \text { Current observed variables } \\
\mathrm{Yt}-1 & : \text { Variables observed one period before } \\
\Delta \mathrm{Yt} & : \mathrm{Yt}-\mathrm{Yt}-1 \\
\mathrm{~T} & : \text { Time trend } \\
\alpha, \beta & : \text { Regression coefficient } \\
\varepsilon & : \text { error terms }
\end{array}
$$


The hypotheses in this test were:

$\mathrm{H} 0: \gamma=0$, which meant that there were unit roots (data was not stationary)

$\mathrm{H} 1: \gamma=/ 0$, which meant that there were unit roots (data was stationary)

After the stationary test was carried out, it was continued with the Granger Causality Test to see if there was a two-way relationship between the variables studied. Ahmadi (2016) employed a model of:

$$
\begin{aligned}
& \mathrm{Yt}=\sum \alpha 1 \mathrm{iYt}-1+\sum \beta 1 \mathrm{iXt}-1+\varepsilon \mathrm{t} \\
& \mathrm{Xt}=\sum \alpha 1 \mathrm{XXt}-1+\sum \beta 1 \mathrm{iYt}-1+\varepsilon \mathrm{t}
\end{aligned}
$$

Description:

Yt : variable y

$\mathrm{Xt}$ : variable $\mathrm{x}$

Yt-1 : variable y one period before

$\mathrm{Xt}-1 \quad$ : variable $\mathrm{x}$ one period before

$\alpha, \beta \quad$ : regression coefficient

$\varepsilon \quad$ : error terms

The hypotheses in this test were:

$\mathrm{H} 0: \beta=0$, which meant that $\mathrm{X}$ did not affect $\mathrm{Y}$

$\mathrm{H} 1: \beta=/ 0$, which meant that $\mathrm{X}$ affects $\mathrm{Y}$

Hypothesis testing in this study was:

- If the probability $<\mu$, then H0 was rejected

- If the probability $>\mu$ then there was no proof to reject $\mathrm{H} 0$

\section{Results and Discussion}

The stationary test results in this study employed Augmented Dickey-Fuller (ADF), if the probability $<0.05$ then the data was stationary.

Table 1. Results of Stationarity Test with the ADF Method in Level Degree

\begin{tabular}{|l|l|}
\hline Variable & Prob. $^{*}$ \\
\hline QERI & 0.2000 \\
\hline FTFLKS & 0.6351 \\
\hline FTDKUS & 0.0000 \\
\hline ISSI & 0.2003 \\
\hline
\end{tabular}

Table 2. Results of Stationarity Test with the ADF Method in First Difference Degree

\begin{tabular}{|l|l|}
\hline Variable & Prob.* $^{*}$ \\
\hline QERI & 0.0000 \\
\hline FTFLKS & 0.0000 \\
\hline FTDKUS & 0.0000 \\
\hline ISSI & 0.0000 \\
\hline
\end{tabular}

The results of the Stationarity Test at the first difference degree showed that all stock price indices had stationary data because they got a probability result of $<0.05$. The QERI index got a probability result of 0.00000 , the FTFLKS index got a probability result of 0.00000 , the FTDKUS index got a probability result of 0.00000 , and the ISSI index got a 
probability result of 0.00000 . From the Stationarity Test results at the first difference degree, it could be seen that all data were stationary. All data showed a probability result of $<0.05$, so it could be concluded that all data were stationary at the first difference degree.

To find the causality results between the sharia stock indices of Qatar (QERI), Kuwait (FTFLKS), and the United Arab Emirates (FTDKUS) with the Indonesia Sharia Stock Index (ISSI), a Granger Causality Test was conducted on the daily data of the sharia stock index for each country. Each country had 1122 data per index which was the total of data on the same sales day. By doing this test, it was known whether there was a two-way causality between the sharia stock price indices of Qatar (QERI), Kuwait (FTFLKS), and the United Arab Emirates (FTDKUS) and the Indonesian Sharia Stock Index (ISSI).

Table 3. Granger Causality Test Results

\begin{tabular}{|l|l|l|l|}
\hline Index & Lags & Obs & Probabilities \\
\hline QERI to ISSI & 5 & 1117 & 0.3714 \\
\hline ISSI to QERI & 5 & 1117 & 0.9742 \\
\hline FTFLKS to ISSI & 4 & 1118 & 0.3105 \\
\hline ISSI to FTFLKS & 4 & 1118 & 0.4966 \\
\hline FTDKUS to ISSI & 8 & 1114 & 0.9764 \\
\hline ISSI to FTDKUS & 8 & 1114 & 0.8583 \\
\hline
\end{tabular}

Based on the results of the Granger Causality Test conducted between the QERI and ISSI indices, it could be observed that the probability result between QERI to ISSI was 0.3714 and ISSI to QERI was 0.9742. This means that H0 was accepted. Therefore, there was no two-way causality relationship between the QERI index and the ISSI because the probability obtained was $<0.05$. Based on the results of the Granger Causality Test conducted between the FTFLKS and ISSI indices, it could be observed that the probability result between FTFLKS to ISSI was 0.3105 and ISSI to FTFLKS was 0.4966. This means that $\mathrm{H} 0$ was accepted. Therefore, there was no two-way causality relationship between the FTFLKS index and the ISSI because the probability obtained was $<0.05$. Based on the results of the Granger Causality Test conducted between the FTDKUS and ISSI indices, it could be observed that the probability result between FTDKUS to ISSI was 0.9764 and ISSI to FTDKUS was 0.8583 . This means that $\mathrm{H} 0$ was accepted. Therefore, there was no two-way causality relationship between the FTDKUS index and the ISSI because the probability obtained was $<0.05$.

The Granger Causality Test results showed that there was no causality relationship between Qatar, Kuwait, and the United Arab Emirates sharia indices and the Indonesian Sharia Stock Index. This happened because according to Shihab (2019) the economic potential between Indonesia and the three countries had not been explored because the three countries only focused on religious funding and had not become major investors for Indonesia so they had little influence on Indonesia. According to Burdah (2017), this happened because the relations between Qatar, Kuwait, and the United Arab Emirates with Indonesia were minimal in productivity because Qatar, Kuwait, and the United Arab Emirates emphasized their productive relations with Europe and America, while Indonesia emphasized their productive relations with ASEAN and Pacific countries. According to Darmin (2017), this occurred because the economic impact generated by Qatar, Kuwait, and the United Arab Emirates was not large because Indonesia had intensified economic relations in the East Asia, South Asia, and China regions. In addition, Utama (2020) said that this could happen because Indonesia was minimally involved in Middle Eastern politics because it followed a foreign policy that was free and active. 


\section{Conclusion}

This study concluded that there was no causality relationship between all sharia stock price indices of Qatar (QERI), Kuwait (FTFLKS), and the United Arab Emirates (FTDKUS) and the Indonesian Sharia Stock Index (ISSI). This study provided different results from the results of previous research, especially regarding the sharia stock index. However, the results of this study could provide input to investors who already had stock portfolios in these countries: if an incident occurred in one of the countries, investors in the sharia capital markets of Qatar, Kuwait, and the United Arab Emirates would not need to react by taking back their investment in Indonesia's capital market and vice versa. Investment options in portfolios in these countries could be a diversification option if an investor was interested in investing in the sharia capital market. Further research needs to be developed using different stock price indices in other countries that have a close relationship.

\section{References}

Adisetiawan, R. \& Ahmadi (2018). Contagion effect antar ASEAN 5. J-MAS ( Jurnal Manajemen dan sains), 3(2), 203-216.

Adityara, E. (2012). Pengaruh Pasar Saham Dunia Terhadap Pasar Saham Indonesia. Jurnal etikonomi, 11(2), 108-125.

Adzimatinur, F., \& Manalu, V. G. (2021). The Effect of Islamic Financial Inclusion on Economic Growth: A Case Study of Islamic Banking in Indonesia. Budapest International Research and Critics Institute (BIRCI-Journal) : Humanities and Social Sciences, 4(1), 976-985.

Afrianto, D. (2017, Juni 06). Timur Tengah Memanas, Menko Darmin: Dampak bagi Ekonomi Indonesia Tidak Besar! Retrieved from okezone.com: https://economy.okezone.com/read/2017/06/06/20/1709081/timur-tengahmemanasmenko-darmin-dampak-bagi-ekonomi-indonesia-tidak-besar

Ahmadi. (2016). Kausalitas dan Indeks Harga Saham 11 Negara Terhadap Indeks Harga Saham Indonesia. Eksis, 1-10.

Asmuni, et al. (2021). Strategic Analysis (BAZNAS) SUMUT on Impossible Assistance and Development in Productive Zakat Management. Budapest International Research and Critics Institute-Journal (BIRCI-Journal). 72-88.

Ata, H. A., \& Bugan, M. F. (2015). Comparison of the performances islamic and conventional markets indicates and their causal relationship. International Journal of Business Management and Economics Research (IJBMER),6(6), 455-462.

Bayram, K., \& Othman, A. H. A. (2019). Islamic Versus Conventional Stock Market Indicates Performance: Empirical Evidence from Turkey. Iqtishadia : Jurnal Kajian Ekonomi dan Bisnis Islam, 12(1), 74-86.

Beik, I. S., \& Fatmawati, S. W. (2014). Pengaruh indeks harga saham syariah international dan variabel makro ekonomi terhadap jakarta islamic index. Al-Iqtishad Journal of Islamic Economics, VI(2), 155-178.

Budi, U. I. W. A., \& Sri, A. L. G. (2015). Pengaruh Indeks Bursa Dunia Pada Indeks Harga Saham Gabungan Bursa Efek Indonesia . Jurnal Manajemen, Strategi Bisnis dan Kewirausahaan, 9(1), 65-73.

Burdah, I. (2017). Media Indonesia. Retrieved from Penguatan Hubungan Indonesia-Timur Tengah: https://mediaindonesia.com/read/detail/94261-penguatanhubunganindonesia-timur-tengah. 
Bursa Efek Indonesia. (2011). Fatwa \& Regulasi. Retrieved from IDX: https://www.idx.co.id/idx-syariah/fatwa-regulasi/

Bursa Efek Indonesia. (2018). Indeks Harga Saham Syariah Indonesia. Retrieved from IDX: https://www.idx.co.id/idx-syariah/indeks-saham-syariah.

Chabachib, H. M., \& Witjaksono, A. A. (2011). Analisis pengaruh fundamental makro dan indeks harga global terhadap IHSG. Karisma, 5(2), 63-72.

Dornbusch, R., et al. (2010). Contagion: Understanding How It Spreads. The World Bank Reseach Observer, 15(2), 177-197.

FTSE Russell. (2019). FTSE Nasdaq Dubai Series. Retrieved from FTSE Russell:

https://www.ftse.com/products/indicates/NASDAQ-Dubai

Ghiffari, M. F., et al. (2017). Hubungan Kausalitas Dow Jones Industrial Average (DJIA), dan Nikkei 225 Terhadap Jakarta Composite Index (JCI) Periode 2011-2016. Jurnal EMBA, 5(2), 445-454.

Gom, H. G. (2013). Analisis Pengaruh The Fed Rate, Indeks Dow Jones, dan Indeks Nikkei25 terhadap indeks harga saham gabungan (IHSG) di Bursa efek Indonesia. Jurnal Ekonomi dan Keuangan, 1(8), 28-38.

Haikal. (2011). Panduan Cerdas \& Syar'i Investasi Syariah Dinar-Emas-SukukReksadana. Yogyakarta: Araska.

Harjito, D. A. (2010). Perubahan musiman (seasonality) pasar modal dan efek kontangion di negara-negara ASEAN. Jurnal siasat bisnis, 14 (1), 1-18.

Indonesia Stock Exchange (2020). Penghargaan Internasional sebagai The Best Islamic Capital Market kembali Diraih BEI pada GIFA 2020 Retrieved From Idx. online: https://www.idx.co.id/berita/press-release-detail/?emitenCode=1376.

Indrabudiman, A., \& Winarningsih, S. (2018). Relationship and Effect on The Dow Jones International Islamic Index. International Journal of Pure and Applied Mathematics, 119(12), 16483-16492.

Investing.com. (2018). Retrieved from Investing.com: Investing.com/graph.

Jebran, K., et al. (2017). Islamic and conventional index co-movement and volatility transmission: evidence from Pakistan. Future Business Journal, 3, 98-106.

Juanda, B,. \& Junaidi. (2012). Ekonometrika Deret Waktu Teori dan Aplikasi. Bogor: IPB Press.

Kemlu. (2018). Tentang KBRI Doha. Retrieved from kemlu.co.id: https://kemlu.go.id/doha/id/pages/tentang_kbri_doha/159/etc-menu.

Kemlu. (2018). Hubungan Bilateral Indonesia - Kuwait. Retrieved from kemlu.co.id: https://kemlu.go.id/kuwaitcity/id/pages/hubungan_bilateral_indonesia_kuwait/1586 letc-menu.

Kemlu. (2018). Persatuan Emirat Arab. Retrieved from kemlu.co.id: https://kemlu.go.id/abudhabi/id/read/persatuan-emirat-arab/2306/etc-menu.

Kumar, A. (2019). Understanding the interdependecy between the nifty 50 future index and the advanced future stock market through econometrics. International Journal of Recent Technology and Engineering (IJRTE), 8(4), 2277-3878.

Lee, H. (2012). Contagion in international stock markets during the sub prime mortgage crisis. International Journal of Economics and Financial Issues, 2(1), 41-53.

Natsir, K. et al. (2019). Analisis kausalitas antara IHSG, indeks dow jones industrial average, dan nilai tukar rupiah/US\$. Jurnal Muara Ilmu Ekonomi dan Bisnis, 3(2), 229-239.

OJK. (2020). Undang-Undang Republik Indonesia Nomor 8 Tahun 1995 Tentang Pasar Modal. Retrieved from OJK: https://www.ojk.go.id/id/kanal/pasar- 
modal/regulasi/undangundang/Documents/Pages/undang-undang-nomor-8-tahun1995-tentangpasar-modal/UU\%20Nomor\%208\%20Tahun\%201995\%20(official).pdf Qatar Stock Exchange. (2018). QE Al Rayan Islamic Index. Retrieved from Qatar Stock Exchange: http://www.qe.com.qa/qe-al-rayan-islamic-index.

Rahmati, A., et al.(2018). Analysis of Low Realization For Mudharabah Financing at Muamalat Indonesia Bank, Banda Aceh. Budapest International Research and Critics Institute (BIRCI-Journal) : Humanities and Social Sciences, 1(4), 215-223.

Rakhal, R. (2015). Determinants of Stock Market Performance. Nepal Commerce Campus, $3(1), 134-142$.

Shihab, M. (2019). Hubungan Indonesia dan Dunia Arab: Potensi Ekonomi yang Belum Tergali. Retrieved from matamata politik: https://www.matamatapolitik.com/analisis-hubungan-indonesia-dandunia-arabpotensi-ekonomi-yang-belum-tergali/.

Sutedi, A. (2011). Pasar Modal Syariah: Sarana Investasi Keuangan Berdasarkan Prinsip Syariah. Bandung: Grafika.

Tandelilin. (2010). Portofolio dan Investasi Teori dan Aplikasi. Yogyakarta: Kanisius.

Treesa J. T., \& Anjali, V. (2018). Driver-Driven Relationship Between The Tokyo Stock Exchange Indicates-TOPIX and NIKKEI. Asian Journal of Management, 9(4), 13191324.

Trihadmini, N. (2012). Contagion Dan Spillover Effect Pasar Keuangan Global Sebagai Early Warning System. Finance and Banking Journal,, 13(1), 47-61.

Uliviano, M. (2013). Analisis Volatilitas Indeks Dow Jones, FTSE 100, Hang Seng, Dan LQ 45 Selama Krisis Eropa: Wavelet Analysis. E-Journal Uajy.

Utama, M. R. (2020). The US-Iran conflict and what it means for Indonesia. Retrieved from: https://theconversation.com/the-us-iran-conflict-and-what-it-means-forindonesia-129621.

Vermonte. (2017). Persamaan ASEAN dengan Timteng dari sisi ekonomi. Retrieved from Jawa Pos: https://www.jawapos.com/pendidikan/11/11/2017/persamaanaseandengan-timteng-dari-sisiekonomi.

Widoatmodjo, S. 2012. Cara Sehat Investasi di Pasar Modal. Edisi Revisi. Jakarta: PT. Jurnalindo Aksara Grafika.

Yusuf, A. H., et al.. (2018). Analisis Kausalitas Harga Saham Konvensional dengan Harga Saham Syariah di Indonesia (Pendekatan Granger Causality). Jurnal Ekonomi Islam, 155-180.

Zahara, F. (2020). The Analysis of Maqashid Syariah on the Use of Fiat Money and Dinar Dirham. Budapest International Research and Critics Institute-Journal (BIRCIJournal). P. 1216-1226. 